\title{
Pengaruh Subtitusi Tepung Terigu dengan Tepung Pisang terhadap Sifat Fisikokimia dan Organoleptik Cookies
}

\section{The Effect of Wheat Flour Substituted by Bananas Flour on Physicochemicals and Cookies Preferences}

Ulfi Nihayatuzzahro Ardiani Yasinta*, Bambang Dwiloka, Nurwantoro

Program Studi Teknologi Pangan, Fakultas Peternakan dan Pertanian, Universitas Diponegoro, Semarang

*Korespondensi dengan penulis (ulfi.sinta@yahoo.com)

Artikel ini dikirim pada tanggal 12 Januari 2017 dan dinyatakan diterima tanggal 28 Juni 2017. Artikel ini juga dipublikasi secara online melalui www.jatp.ift.or.id. Hak cipta dilindungi undang-undang. Dilarang diperbanyak untuk tujuan komersial.

Diproduksi oleh Indonesian Food Technologists® (C2017

\begin{abstract}
Abstrak
Penelitian subtitusi tepung terigu dengan tepung pisang terhadap sifat fisikokimia dan organoleptik cookies ini dilakukan untuk mengetahui pengaruh dari tepung pisang sebagai agensia pensubtitusi tepung terigu terhadap sifat fisikokimia dan organoleptik cookies. Rancangan yang digunakan pada penelitian ini yaitu Rancangan Acak Lengkap (RAL) dengan 4 perlakuan dan 5 kali ulangan yang terdiri dari P0: 100\% tepung terigu tanpa tepung pisang, $\mathrm{P} 1$ : $75 \%$ tepung terigu dan $25 \%$ tepung pisang, $\mathrm{P} 2$ : $50 \%$ tepung terigu dan $50 \%$ tepung pisang, $\mathrm{P} 3$ : $25 \%$ tepung terigu dan $75 \%$ tepung pisang. Subtitusi yang dilakukan memberikan pengaruh pada semua pengujian $(\mathrm{P}<0,05)$ kecuali padatan terlarut dan rasa manis. Warna cookies mengalami perubahan. Semakin tingginya subtitusi tepung pisang maka warna cookies semakin cokelat pekat oleh subtitusi $75 \%$ dengan nilai 53,68 . Pada atribut tekstur paling renyah adalah perlakuan $75 \%$. Kadar air cookies mengalami penurunan dengan semakin banyaknya tepung pisang. Kadar air yang tertinggi dimiliki oleh cookies kontrol dengan nilai 9,63\%. Pada padatan terlarut tidak ada perbedaan di setiap subtitusi. Hasil pengujian uji organoleptik kesukaan yang paling disukai panelis adalah perlakuan P2 dengan konsentrasi tepung pisang $50 \%$ dan tepung terigu $50 \%$. Semakin besar konsentrasi substitusi tepung pisang maka menurunkan kesukaan secara keseluruhan karena rasa cookies menjadi hambar.
\end{abstract}

Kata kunci: cookies, tepung pisang, tepung terigu

\begin{abstract}
The research was done to determine the effect of banana flour as a substitution for wheat flour based on the physicochemical and preferences properties of cookies. The design used in this study was completely randomized design (CRD) with 4 treatments and 5 replication. The treatment consisting of P0: 100\% wheat flour without banana flour, P1: $75 \%$ flour and 25\% of banana flour, P2: $50 \%$ flour and 50\% banana flour, P3: $25 \%$ flour and $75 \%$ respectively of banana flour. All the treatments were gave significant effect excluded on the total solid dissolved and sweet properties. The properties of colour had changed being darker with the value $53,68 \%$ at the $75 \%$ level of substitution. The most crunchy texture attributes was gained at the treatment of $75 \%$ level of substitution. However, the water content of cookies had decreased while the increasing number of banana flour addition. The highest level on water content properties was gained with the value $9.63 \%$. Moreover, there was no significant different for the total dissolved properties at any level of treatments. Based on the panellist preferences, P2 (substitution of 50\%) being the most preferable within any treatments. The cookies gradually being tasteless when the substitution of banana flour getting high.
\end{abstract}

Keywords: cookies, banana flour, wheat flour

\section{Pendahuluan}

Cookies merupakan salah satu produk bakery yang populer di semua kalangan, terbuat dari tepung terigu namun tidak memerlukan pengembangan (unleavened product) melalui proses pencetakan dan pemanggangan serta diutamakan kerenyahan teksturnya dengan kadar air yang harus kurang dari $5 \%$ (Utami, 1991)

Cookies umumnya berbahan baku tepung terigu. Ketergantungan dengan gandum import perlu diberikan perhatian khusus dalam upaya meningkatkan pengembangan pangan alternatif sebagai bahan substitusi atau pengganti terigu agar tidak selalu mengandalkan tepung terigu impor dan mampu memanfaatkan sumber daya lokal. Salah satu bahan pangan yang dapat digunakan sebagai pengganti tepung terigu adalah tepung pisang dalam pembuatan cookies, karena produksi buah pisang sangat melimpah di Indonesia namun masih terbatas pengolahannya. Alasan lainnya karena pisang mengandung berbagai macam vitamin seperti vitamin $A$, vitamin $B$, vitamin $C$, buah pisang juga mengandung mineral seperti fosfor, kalsium, dan besi. Pisang mengandung pati sebanyak $61,3-76,5 \mathrm{~g} / 100 \mathrm{~g}$ berat kering dan kandungan serat sebanyak 6,3-15,5 g/100 g berat kering (Noor et al., 2012).

Asupan serat makanan yang tinggi memiliki efek menguntungkan pada kesehatan manusia sehingga tepung yang terbuat dari buah pisang ini berpotensi untuk dijadikan alternatif pangan fungsional. Penelitian sebelumnya melaporkan bahwa subtitusi tepung pisang berpotensi untuk memberikan asupan tambahan energi karena bahan dasar tepung pisang yang mengandung karbohidrat tinggi (Desiana et al., 2012).

Cookies mampu diproduksi dengan menggunakan berbagai macam tepung termasuk tepung yang berprotein rendah serta tidak mengandung gluten karena cookies tidak membutuhkan pengembangan (Gayati, 2014). Tepung pisang mengandung karbohidrat yang tinggi serta daya simpan 
yang panjang, sehingga dapat menggantikan sebagai konsumsi beras dan terigu (Sulusi et al., 2008).

Penelitian ini dilakukan dengan tujuan untuk mengetahui pengaruh dari tepung pisang sebagai agensia pensubtitusi tepung terigu terhadap sifat fisikokimia dan organoleptik cookies. Pemanfaatan tepung lokal seperti tepung pisang sebagai subtitusi tepung terigu dalam pembuatan cookies diharapkan dapat meningkatkan kualitas cookies dan mengangkat potensi pangan lokal.

\section{Materi dan Metode Materi}

Alat yang digunakan dalam pembuatan cookies yaitu sutil, sendok, mangkuk, gelas ukur, wajan, kompor, oven, loyang, kuas, baskom, mixer, penggilas adonan, cetakan cookies, timbangan. Alat pengujian kadar air yakni timbangan analitik, cawan, penjepit, desikator, dan oven. Alat pengujian tekstur yaitu wadah kaca dan texture analyzer Brookfield CT3. Uji warna menggunakan digital color meter dan plastik transparan. Uji padatan terlarut menggunakan refraktometer. Uji organoleptik dilakukan dengan penilaian kuesioner yang kemudian dibagikan pada 20 panelis agak terlatih. Bahan yang digunakan dalam pembuatan cookies (dalam satu unit adonan) adalah: margarin $150 \mathrm{~g}$, gula bubuk $50 \mathrm{~g}$, susu skim $25 \mathrm{~g}$, kuning telur 2 butir, tepung terigu protein rendah $250 \mathrm{~g}$, tepung meizena $10 \mathrm{~g}$, vanilla $1 / 2$ sendok teh, garam $1 / 2$ sendok kecil dan tepung pisang (sesuai perlakuan yang diterapkan). Bahan yang digunakan untuk uji kadar air, volume pengembangan, padatan terlarut dan analisis fisik warna, tekstur dan organoleptik adalah sampel cookies.

\section{Metode}

Penelitian dilakukan dalam beberapa bagian diantaranya pembuatan cookies, pemberian perlakuan dan pengujian parameter penelitian.

\section{Pembuatan cookies}

Pembuatan cookies terdiri dari tiga tahap, yaitu pembuatan adonan, pencetakan dan pemanggangan. Dalam pembuatan adonan, pertama kali yang dimasukkan adalah mentega $150 \mathrm{gr}$, gula bubuk 50gr, dan susu skim $25 \mathrm{gr}$ dicampurkan dengan mixer kurang lebih 3-7 menit, dilanjutkan dengan memasukkan 2 butir kuning telur setelah mengembang dan berubah warna lalu tepung pisang dan tepung terigu sesuai perlakuan dimasukkan kemudian dimixer kembali hingga 5 menit. Pencetakan dilakukan agar mendapatkan produk cookies yang bentuknya seragam lalu diletakkan dalam loyang yang sebelumnya sudah dilumuri mentega. Proses pemanggangan cookies berkisar antara 180-200oC selama 16-20 menit (Erny et al., 2013).

\section{Pemberian perlakuan}

Penelitian ini menggunakan desain penelitian Rancangan Acak Lengkap (RAL) dengan 4 perlakuan dan 5 perlakuan yang terdiri dari P0: 100\% tepung terigu tanpa tepung pisang, $\mathrm{P} 1: 75 \%$ tepung terigu dan $25 \%$ tepung pisang, P2: $50 \%$ tepung terigu dan $50 \%$ tepung pisang, P3: $25 \%$ tepung terigu dan $75 \%$ tepung pisang. Setiap cookies yang telah dibuat dengan perlakuan yang berbeda dilakukan pengujian warna, tekstur, kadar air, padatan terlarut dan organoleptik yang mencakup warna, aroma, rasa, tekstur dan kesukaan.

\section{Pengujian parameter penelitian}

Pengujian warna menggunakan alat digital color meter, pengujian tekstur menggunakan metode Texture Profile Analysis (TPA) dengan LLOYD texture analyzer, Pengujian kadar air dengan menggunakan metode pengovenan (Legowo et al., 2005). Pengujian organoleptik menggunakan panelis agak terlatih dengan jumlah panelis sebanyak 20 orang.

\section{Analisis statistik}

Pengolahan data dilakukan dengan bantuan program SPSS 16.0 for windows. Hasil analisis yang signifikan dilanjutkan dengan pengujian Duncan's Multiple Range Test (DMRT) (Gomez dan Gomez, 1995). Pengolahan Data hasil pengujian organoleptik dengan parameter rasa, warna, aroma, tekstur, dan kesukaan dianalisis dengan menggunakan uji KruskalWallis, jika terdapat pengaruh nyata terhadap perlakuan maka dilanjutkan uji Mann Whitney (Sujana, 1994) dalam beberapa

\section{Hasil dan Pembahasan}

Pengaruh Subtitusi Tepung Terigu dengan Tepung Pisang terhadap Sifat Fisik Cookies

Berdasarkan hasil pengamatan pada sifat fisik warna, dapat diketahui bahwa nilai $L$ (kecerahan) cenderung mengalami penurunan bila dilihat berdasarkan perlakuan substitusi tepung. Kecerahan tertinggi yakni pada perlakuan kontrol tanpa penambahan tepung pisang. Nilai $L$ (kecerahan) terendah terdapat pada perlakuan dengan subtitusi pisang tertinggi $75 \%$ karena menghasilkan warna yang paling gelap, semakin banyaknya subtitusi tepung pisang, maka angka kecerahan menurun. Warna yang dihasilkan oleh cookies dipengaruhi oleh konsentrasi substitusi tepung pisang. Semakin tinggi konsentrasi

Tabel 1. Hasil Nilai Warna, Nilai Tekstur, Kadar Air dan Nilai Padatan Terlarut pada Subtitusi Tepung Terigu dengan Tepung Pisang terhadap Sifat Fisikokimia Cookies.

\begin{tabular}{ccccc}
\hline \multicolumn{1}{c}{ Perlakuan } & \multicolumn{2}{c}{ Rerata } & Nilai Padatan Terlarut $\left(^{\circ}\right.$ Brix $)$ \\
\hline P0 & $69,38 \pm 5,0^{\mathrm{a}}$ & $791,6 \pm 19.230^{\mathrm{a}}$ & $9,63 \pm 0,99^{\mathrm{a}}$ & $12,8 \pm 0,837^{\mathrm{ns}}$ \\
P1 & $68,45 \pm 10,5^{\mathrm{a}}$ & $991,42 \pm 19.240^{\mathrm{a}}$ & $6,87 \pm 1,03^{\mathrm{b}}$ & $13,6 \pm 3,647^{\mathrm{ns}}$ \\
P2 & $59,32 \pm 7,81^{\mathrm{ab}}$ & $1039,7 \pm 19.993^{\mathrm{b}}$ & $5,73 \pm 0,87^{\mathrm{bc}}$ & $14,4 \pm 3,36^{\mathrm{ns}}$ \\
P3 & $53,68 \pm 40,3^{\mathrm{b}}$ & $1131,75 \pm 20,087^{\mathrm{b}}$ & $5,45 \pm 0,87^{\mathrm{c}}$ & $13,8 \pm 2,38^{\mathrm{ns}}$ \\
\hline
\end{tabular}


tepung pisang yang ditambahkan maka semakin coklat warna cookies yang dihasilkan karena kandungan tepung pisang yang identik dengan gula di dalamnya dan bahan dasar tepung pisang yang kecoklatan. Sesuai dengan pendapat Winarno (2004) bahwa adanya kandungan vitamin $\mathrm{C}$ pada pisang yang membuat terjadinya pencoklatan pada proses pembuatan pati sehingga menyebabkan terjadinya warna kecoklatan pada pisang. Selain itu tepung pisang yang digunakan untuk pembuatan cookies mengandung gula yang tinggi yaitu 18,24 - 20,04 (Winarno 2004). Kandungan gula yang cukup tinggi tersebut menyebabkan adanya reaksi Maillard yang mengakibatkan perubahan warna selama proses pemanggangan menjadi kecokelatan.

Berdasarkan hasil pengamatan pada sifat fisik tekstur yang hasilnya signifikan pada Tabel 1 dapat diketahui bahwa keempat perlakuan mendapatkan hasil berbeda nyata $(P<0,05)$. Semakin tinggi subtitusi tepung pisang semakin renyah cookies yang dihasilkan. Hal ini disebabkan karena semakin tinggi subtitusi tepung pisang menyebabkan kerenyahan pada cookies akibat kadar air yang terkandung pada tepung pisang menjadi lebih rendah dibanding tepung terigu. Tingkat substitusi tepung pisang yang semakin tinggi menjadikan nilai tekstur cookies semakin renyahan. Hal ini disebabkan adanya kandungan serat. Serat merupakan salah satu bahan pangan yang terbentuk dari dinding sel tanaman yang keras sehingga mempengaruhi kerenyahan dari cookies (Andarwulan et al., 2011).

Pengaruh Subtitusi Tepung Terigu dengan Tepung Pisang terhadap Kadar Air Cookies

Kadar air yang diperoleh dari cookies dengan substitusi tepung pisang dengan konsentrasi 25\%, 50\% dan $75 \%$ berkisar antara 5,45 - 9,63\%. Hasil analisis (Tabel 1) menunjukkan bahwa terdapat perbedaan kadar air yang signifikan antara cookies yang disubstitusi dengan tepung pisang dengan konsentrasi $25 \%$, 50\% dan $75 \%$ serta kontrol. Cookies dengan konsentrasi tepung terigu $100 \%$ (kontrol) tanpa penambahan tepung pisang memiliki nilai kadar air tertinggi yaitu sebesar $9,63 \%$ sedangkan cookies dengan konsentrasi tepung pisang $75 \%$ memiliki nilai kadar air terendah yaitu sebesar 5,45 \%. Kadar air cookies dengan konsentrasi tepung pisang $0 \%$ berbeda nyata $(\mathrm{P}<0.05)$ dengan kadar air cookies dengan konsentrasi tepung pisang 25\%, 50\%, dan $75 \%$. Berdasarkan standar mutu SNI 01-2973-1992, kadar air cookies yaitu maksimal sebesar $5 \%$ sehingga cookies dengan substitusi tepung pisang dengan konsentrasi $25 \%$, dan $50 \%$ belum memenuhi syarat, namun pada konsentrasi $75 \%$ justru memenuhi syarat. Semakin tinggi subtitusi tepung pisang pada adonan cookies justru menjadikan kandungan kadar air pada produk semakin kecil dan sebaliknya. Hal tersebut disebabkan oleh kadar air dari bahan baku cookies yang berupa tepung terigu adalah sebesar $14 \%$ lebih tinggi dibanding bahan substitusi cookies berupa tepung pisang yaitu sebesar $8,66 \%$. Hal ini sesuai dengan pendapat Syarief dan Hariyadi (1993) yang menyatakan bahwa tinggi rendahnya kadar air suatu bahan sangat ditentukan oleh air terikat dan air bebas yang terdapat dalam bahan tersebut. Karena bahan baku cookies tepung terigu kadar airnya lebih tinggi dari tepung pisang sehingga menyebabkan kadar air biskuit dengan subtitusi tepung pisang yang paling tinggi justru lebih rendah.

\section{Pengaruh Subtitusi Tepung Terigu dengan Tepung Pisang terhadap Padatan Terlarut Cookies}

Berdasarkan hasil penelitian yang telah dilakukan pada uji total padatan terlarut (TPT), hasil subtitusi tepung terigu dengan tepung pisang terhadap sifat fisikokimia cookies dengan perlakuan yang berbeda didapatkan hasil $(12,8 \pm 0,837)^{\circ}$ Brix pada kontrol, $\mathrm{P} 1=(13,6 \pm 3,647){ }^{\circ} \mathrm{Brix}, \mathrm{P} 2=(14,4 \pm 3,36){ }^{\circ}$ Brix, $\mathrm{P} 3=(13,8 \pm 2,38){ }^{\circ}$ Brix. Pada Tabel 1. terlihat bahwa tidak ada perbedaan nyata $(P>0,05)$ pada semua perlakuan baik $0 \%$ tepung pisang maupun $25 \%, 50 \%$ dan $75 \%$ subtitusi tepung pisang. Hal ini disebabkan karena bahan baku tepung pisang yang digunakan berasal dari buah pisang dengan tingkat kematangan tiga perempat matang, yang mana pada kondisi tersebut kandungan patinya telah mencapai maksimal serta belum tereduksi menjadi gula sederhana dan komponen lainnya dalam keadaan seimbang. Apabila buah melewati tiga perempat penuh maka akan terjadi kesulitan selama pengeringan dan tepung pisang bersifat lembek, sedangkan buah dengan kematangan kurang dari tiga perempat penuh akan menghasilkan tepung pisang terasa sedikit pahit dan sepat karena kadar asam serta kadar patinya yang tinggi, karena bahan baku yang tidak terlalu manis tersebut berarti gula yang terkandung relatif rendah sehingga kadar padatan terlarut tidak berpengaruh (Masli, 2007).

\section{Pengaruh Subtitusi Tepung Terigu dengan Tepung Pisang terhadap Sifat Organoleptik Cookies}

Berdasarkan data pada Tabel 2. tentang hasil pengujian organoleptik terhadap rasa cookies substitusi tepung terigu dengan tepung pisang, dapat dilihat bahwa diantara semua perlakuan subtitusi tepung pisang 0\%(P0), 25\%(P1), 50\%(P2) dan 75\%(P3) tidak terdapat beda nyata $(P>0,05)$. Hasil tersebut menjadikan rasa produk cookies yang tidak berubah dari kontrol. Hal tersebut dikarenakan penggunaan

Tabel 2. Hasil Uji Organoleptik Substitusi Tepung Terigu dengan Tepung Pisang terhadap Sifat Fisikokimia

\begin{tabular}{|c|c|c|c|c|}
\hline \multirow{2}{*}{ Parameter Organoleptik } & \multicolumn{4}{|c|}{ Konsentrasi Tepung pisang } \\
\hline & P0 & P1 & P2 & P3 \\
\hline Rasa manis & $2,66 \pm 0,56^{\mathrm{ns}}$ & $2,72 \pm 0,39^{\mathrm{ns}}$ & $2,55 \pm 0,60^{\mathrm{ns}}$ & $2,69 \pm 0,65^{\mathrm{ns}}$ \\
\hline Warna cokelat & $1,23 \pm 0,42^{a}$ & $2,20 \pm 0,40^{b}$ & $3,03 \pm 0,29^{a}$ & $3,78 \pm 0,36^{d}$ \\
\hline Aroma karamel & $1,95 \pm 0,79^{a}$ & $2,23 \pm 0,66^{a}$ & $2,67 \pm 0,56^{\mathrm{b}}$ & $2,73 \pm 0,94^{b}$ \\
\hline Tekstur kerenyahan & $1,81 \pm 0,63^{a}$ & $2,28 \pm 0,61^{b}$ & $3,15 \pm 0,63^{\mathrm{c}}$ & $2,76 \pm 0,69^{c}$ \\
\hline Kesukaan over all & $2,70 \pm 0,71^{\mathrm{a}}$ & $2,69 \pm 0,51^{a}$ & $3,06 \pm 0,81^{a}$ & $2,31 \pm 0,82^{\mathrm{b}}$ \\
\hline
\end{tabular}


bahan baku tepung pisang berasal dari buah pisang dengan tingkat kematangan tiga perempat matang belum tereduksi menjadi gula sehingga tidak ada rasa manis pada tepung pisang sama halnya tidak adanya rasa manis pada tepung terigu karena kadar gula yang relatif rendah dimana keduanya menjadi bahan baku cookies (Masli, 2007).

Parameter warna, berdasarkan penilaian panelis menunjukkan bahwa diantara semua perlakuan berbeda nyata, yang artinya $0 \%(\mathrm{P} 0), 25 \% \quad(\mathrm{P} 1)$, $50 \%$ (P2) dan $75 \%$ (P3) menghasilkan cookies dengan warna yang berbeda beda pada tiap subtitusi. Warna yang coklat keemasan adalah pada konsentrasi $25 \%$ (P1) dan yang sangat coklat adalah dengan konsentrasi $75 \%$ (P3). Warna yang dihasilkan cookies dipengaruhi oleh substitusi tepung pisang, semakin tinggi konsentrasi tepung pisang yang ditambahkan maka semakin coklat warna cookies yang dihasilkan. Hal ini dapat dikaitkan dengan hasil uji warna menggunakan alat color meter, dimana cookies P0 sebagai kontrol memiliki warna paling cerah (nilai kecerahan tertinggi sebesar 69,38) sedangkan P1 hingga P3 nilainya semakin rendah yang artinya tingkat kecerahan warna semakin gelap dikarenakan reaksi Maillard. Sesuai pendapat Avianty dan Ayustaningwarno (2013) bahwa warna kecokelatan dapat dihasilkan oleh reaksi Maillard antara asam amino lisin yang kandungannya tinggi pada pisang dengan gugus gula pereduksi.

Penilaian panelis terhadap aroma menunjukkan bahwa aroma karamel yang paling terasa adalah konsentrasi $75 \%$ (P3) dan yang tidak beraroma karamel adalah konsentrasi $0 \%$ (P1). Aroma yang dihasilkan oleh cookies subtitusi tepung pisang dengan berbagai konsentrasi dipengaruhi oleh aroma khas karamel yang dimiliki oleh tepung pisang. Menurut Sitohang et al. (2015), bau khas adonan ditimbulkan dari komponen pada adonan seperti pencampuran margarin dan telur, aroma cookies juga dipengaruhi oleh proses pemanggangan dimana tingkat kehilangan air pada saat proses pemanggangan yang menyebabkan terjadinya penguapan dari dalam adonan.

Sementara itu, pada parameter tekstur, berdasarkan penilaian panelis menunjukkan bahwa tekstur yang sangat renyah adalah konsentrasi subtitusi pisang $50 \%$ (P2) dan yang tidak renyah adalah konsentrasi $0 \%$ (P0). Artinya, kerenyahan tertinggi justru pada subtitusi tepung pisang $50 \%$. Tekstur pada cookies ditentukan oleh kadar air, hal ini dapat dikaitkan karena kandungan kadar air pada tepung terigu 14\% lebih tinggi dibanding tepung pisang yaitu $11 \%$. Kemudahan patah sangat dipengaruhi oleh kadar air. Kandungan air dalam suatu bahan yang semakin sedikit menjadikan tekstur menjadi semakin kering sehingga akan mengakibatkan cookies yang lebih mudah patah. Hal ini sesuai dengan pernyataan Singh et al. (2008) yang melakukan penelitian mengenai tekstur dari cookies. Berbagai macam hal yang mempengaruhi tekstur dari cookies salah satunya adalah kadar air. Menurut Piga et al. (2015), kandungan air di dalam cookies sangat mempengaruhi parameter.

Penilaian panelis terhadap kesukaan menunjukkan bahwa kesukaan yang sangat disukai adalah konsentrasi $50 \%$ (P2) dan yang tidak disukai adalah subtitusi $75 \%$ (P3). Pengujian kesukaan keseluruhan merupakan penilaian terhadap semua faktor mutu meliputi warna, rasa, aroma, dan tekstur. Nilai kesukaan panelis terhadap parameter kesukaan dilihat dari rasa, warna, aroma, dan tekstur yang paling disukai adalah cookies tepung pisang pada konsentrasi $50 \%$. Artinya pada perlakuan $50 \%$ terigu dan $50 \%$ pisang justru disukai oleh banyak panelis dibanding dengan cookies umum yang hanya menggunakan tepung terigu saja. Hal ini dikarenakan komposisi keduanya seimbang antara tepung terigu dan tepung pisang dimana keduanya berkolaborasi saling memenuhi kekurangan pada masing-masing bahan pembuatan cookies. Perlakuan $50 \%$ cookies yang biasanya terbuat dari tepung terigu menjadi unik dan gurih dengan adanya subtitusi tepung pisang. Hal tersebut juga terkait dengan berkurangnya protein gluten yang terkandung dalam adonan. Gluten sebagai bahan pengikat masih dibutuhkan oleh cookies yang fungsinya dalam pembentukan tekstur pada cookies menjadi renyah namun tidak terlalu mendominasi seperti pada pengolahan produk bakery lainya (Hartoyo, 2006).

\section{Kesimpulan}

Berdasarkan hasil penelitian tentang pengaruh subtitusi tepung terigu dengan tepung pisang terhadap sifat fisikokimia cookies diketahui bahwa warna, tekstur dan kadar air cookies terdapat perbedaan. Semakin banyak penambahan subtitusi tepung pisang semakin gelap warna yang dihasilkan namun semakin renyah tekstur cookies, karena kadar air tepung pisang lebih rendah dibanding tepung terigu. Hasil penelitian pada pengujian organoleptik dengan parameter tekstur, warna, aroma, rasa, dan kesukaan, diperoleh hasil yang terbaik yaitu pada cookies dengan perlakuan substitusi tepung $50 \%$.

\section{Daftar Pustaka}

Andarwulan, N., Kusnandar, F., Herawati, D. 2011. Analisis Pangan. PT. Dian Rakyat, Jakarta.

Avianti, S., Ayustaningwarno, F. 2013. Kandungan zat gizi dan tingkat kesukaan snack bar ubi jalar kedelai hitam sebagai alternatif makanan selingan penderita diabetes melitus tipe 2. J. Nutrition College, 4(2), 622-629.

Desiana, M., Budi, W., Ahmad, S., Budi, S. 2012. Uji Organoleptik biskuit dan flake campuran tepung pisang dengan kurma sebagai suplemen bagi olahragawan. J. TIBBS, 3, 7-13

Erny, J. N., Mandey, L., Lelemboto. 2013. Karakteristik fisikokimia biskuit berbahan baku tepung pisang goroho (Musa acuminate,sp). J. Food Science, 2, 5-7

Gayati, I. A. P. 2014. Pemanfaatan Tepung Kacang Koro Pedang (Canavalia ensiformis [L.] DC) dan Tepung Mocaf (Modified Cassava Flour) Pada Cookies Ditinjau dari Sifat Fisiko Kimia dan Sensori. Universitas Katolik Soegijapranata. Semarang.

Gomez, A. A., Gomez, K. A. 1995. Prosedur Statistik untuk Penelitian Pertanian. Diterjemahkan oleh E. Syamsuddin dan Justika S. B. UI Press, Jakarta. 
Hartoyo A. 2006. Pemanfaatan tepung komposit ubi jalar putih, kecambah kedelai, dan kecambah kacang hijau sebagai subtituen parsial terigu dalam produk pangan alternatif biskuit kaya energi protein. J. Teknologi dan Industri Pangan, 17(1), 50-57.

Legowo, A. M., Nurwantoro, Sutaryo. 2005. Analisis Pangan. Badan Penerbit Universitas Diponegoro, Semarang.

Masli, R. 2007. Studi Pembuatan Tepung Pisang Kepok (Musa paradisiaca forma typical) sebagai Bahan Substitusi Pembuatan Roti Tawar (Kajian Tingkat Kematangan Pisang Kepok dan Suhu Pengeringan). Universitas Muhammadiyah Malang.

Noor Aziah, A. A., Ho, L. H., Noor Shazliana, A. A., Rajeev Bhat. 2012. Quality evaluation of steamed wheat bread substituted with green banana flour. International Food Research Journal, 19 (3), 869-876

Normasari, R. Y. 2010. Kajian Penggunaan Tepung Mocaf (Modified Cassava Flour) Sebagai Substitusi Terigu yang Difortifikasi dengan Tepung Kacang Hijau dan Prediksi Umur Simpan Cookies. Universitas Sebelas Maret. Surakarta

Piga, A., Catzeddu, P., Farris, S., Roggio, T., Sanguinetti, A., Scano, E. 2005. Textural Evaluation of Amaretti Cookies during Storage. Food Res. Technol., 221, 387-391.
Pomeranz, Y., Meloan, C.E. 1987. Food analysis : Theory and practice 2nd Edition. An Avi Published by Van Nostrand Reinhold Company, New York.

Singh, C., Riar, S., Saxena, D. C. 2008. Effect of incorporating sweetpotato flour to wheat flour on the quality characteristics of cookies. African J. Food Science, 2, 65-72.

Sitohang, K. A. K., Lubis, Z., Lubis, L. M. 2015. Pengaruh perbandingan jumlah tepung terigu dan tepung sukun dengan jenis penstabil terhadap mutu cookies sukun. Jurnal Rekayasa Pangan dan Pertanian, 3(3), 308-315.

SNI (Standarisasi Nasional Indonesia) 01-2973-1992 tentang Biskuit. 1992. Dewan Standarisasi Nasional. Jakarta.

Sujana. 1994. Desain dan Analisis Eksperimen (Edisi ketiga). PT. Tarsito. Bandung.

Sulusi, P., Suyanti, Dondy A. Setyabudi. 2008. Teknologi Pasca Panen dan Teknik Pengolahan Buah Pisang, Balai Besar Penelitian dan Pengembangan Pascapanen Pertanian Badan Penelitan dan Pengembangan Pertanian (Juknis Pisang).

Syarief, R., Hariyadi, H. 1993. Teknologi Penyimpanan Pangan. Arcan. Jakarta.

Utami, I. S. 1992. Pengolahan Roti. PAU Pangan dan Gizi. Universitas Gadjah Mada. Yogyakarta

Winarno, F. G. 1992. Kimia Pangan dan Gizi. PT.Gramedia Pustaka Umum. Jakarta 